three pale longitudinal bands, evanescent posteriorly before reaching the scutellum. Halteres yellow, club large, somewhat longer than its pedicel. Abdomen shovel shaped, deep chrome yellow, thinly pubescent above with whitish hairs, which give it a sericeous appearance in certain lights.

Legs pale yellow, tibiae slightly dusky, tarsi blackish at their distal ends, otherwise brownish.

Wings clear, iridescent, veins dark brown, the first longitudinal paler.

$H a b$. On yellow flowers of Compositae, grounds of Agricultural College, Las Cruces, N. M., Sept. I894 (Miss F. Casad).
A $\delta$ was taken at San Augustine, N. M., on flowers, Aug. 29, 1894 (Ckll., 2260). It

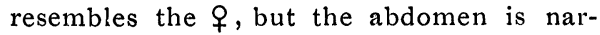
rower and the eyes are contiguous.

This species is interesting from its colour, which is exactly that of the flowers it frequents. It occurs on the same flowers as the similarly colored bee, Perdita luteola Ckll. ined. Prof. C. H. T. Townsend tells me that he remembers finding a similar species in Michigan, but it was not determined.

[This paper was received as the description of a new Dipteron and its true character learned only in time to change the title. ED.]

\title{
LIFE HISTORY OF CLISIOCAMPA FRAGILIS STRETCH.
}

\section{BY HARRISON G. DYAR, A. M., NEW YORK.}

C. FRAGILIS Stretch. I881 - Stretch, Papilio, i, 64 . incurva $\mathrm{Hy}$. Edwards. I882-Hy. Edw., Papilio, ii, I 25. discolorata Neumoegen. I893-Neum., can. ent., xxv, 4 . var. Perlutea Neumoegen and Dyar. I893-N. and D., Journ. N. Y. ent. soc., i, 3 r.

var. Constrictina Neumoegen and Dyar. $1893-N$. and D., Journ. N. Y. ent. soc., i, 30 .

lutescens Neumoegen and Dyar. I893 - N. and D., Journ. N. Y. ent. soc. i, $3 \mathbf{r}$.

var. MUs Neumoegen. 1893-Neum., Can. ent., xxv, 4. var. AzTECA Neumoegen.

r 893 - Neum., Can. ent., xxv, 5.

\section{Synopsis of Varieties.}

Fore wings all pale luteous . Fore wings partly brown

perlutea. constrictina. Fore wings brown, the lines only pale or slightly spreading . . . fragilis. Fore wings dark gray brown . . mus. Fore wings darker, blackish . . azteca.
I know of the larva from Nevada (Prof. J. J. Rivers), Montana (Mr. C. A. Wiley), Colorado (Mr. H. W. Nash) and Wyoming. I feel satisfied from a comparison of bred and captured specimens from these and other localities that there is only this one species from the Rocky Mountains to the Sierras and from Canada (Mr. F. H. Wolley Dod) to Mexico. C. fragilis is the western representative of americana, and is in turn represented in the Pacific Northwest by pluvialis. C. disstria extends throughout the ranges of americana and pluvialis and also extends into Califorhia (erosa and thoracica are synonyms); but does not enter the range of fragilis to my knowledge.* The other species (californica, constricta and ambisimilis) appear to be confined to California, and are yet imperfectly worked out. The following life history is based on larvae bred from eggs kindly sent me by Mr. H. W. Nash of Pueblo, Col.

Eggs. Columnar, flat above, rounded below; upper surface round or elliptical

* Since the above was written, I have seen disstria from Guadalajara, Mexico. 
with a concentric grove; white, smooth, stained by the brown covering froth in an angular marking, corresponding to the edges of the individual bubbles. Shell rather thick, opaque, pearly inside. Laid close together on the rounded end in a single layered columnar mass forming a band reaching half way round a twig or a patch on the side of a larger stem near the ground (Wiley). Froth rather light brown with shining continuous surface.

First stage. Head rounded, shining black; width $0.4 \mathrm{~mm}$. Body black, not shining, marked by a double row of minute orange dots subdorsally. Hair nearly white, quite thick, curving forward dorsally and backward subventrally. A narrow subventral line and tips of abdominal feet pale. Later the subdorsal orange patches become large, distinct on joints 5 to ro. Each patch is narrowed centrally at the large wart $i$ and is widest posteriorly in the middle of which is the small obscure wart ii. The warts bear several hairs but are not well marked.

Second stage. Head black; bases of antennae whitish; width $0.6-0.65 \mathrm{~mm}$. Body black with a narrow, straight, reddish ad-dorsal line, slightly spreading at the anterior and posterior edge of each segment, absent at the extremities. A white subventral line and fainter substigmatal one. Dorsal hair reddish, subventral hair paler. Segmental incisures pale, giving a banded appearance when the body is bent. There are now some short hairs from the skin.

Third stage. Black, hair abundant, reddish dorsally, white subventrally. Width of head I.I-I.I5 mm. Red ad-dorsal line slight, rather broken; subventral pale line quite distinct, substigmatal line faint, venter grayish. No other marks at first, but later a series of narrow, elliptical, dorsal blue spots with pointed ends distinct only centrally, closely bordered by the pulverulent, narrow, red ad-dorsal line. In the subdorsal space traces of blue dots. The red marks are much more reduced than in the previous stage.
Fourth stage. Head powdery blue, black below, bases of antennae and line above the mouth white; width I.8-2.0 mm. Body black, thickly covered with powdery blue up to and enclosing the position of the subdorsa! blue dots, leaving a series of segmentary lateral black patches. Dorsal space black, containing a rather broad dorsal blue band, broken at incisures and the single crinkled and broken orange ad-dorsal line. Hair red, thickest dorsally and subventrally and paler subventrally. Joints I 2 and I3 unornamented, powdery blue. There is considerable variation in the amount of blue laterally. In some, the lateral black spots form a continuous band, separating a blue band corresponding to the dots; some have this band broken into the ordinary spots and only streaks of blue below and then the orange is better developed, showing a little of its subdorsal portion as well as the addorsal portion stronger than usual. The dorsal line is continuous in a few, paler blue than the lateral area. The other lines are obsolete.

Fifth stage. (Interpolated stage.*) Like the last stage, but the blue a little less whitish and not so confluent. Width of head 2.2-2.4 $\mathrm{mm}$.

Fifth (or sixth) stage. Head powdery blue with black dots; antennae whitish at base; line above mouth pale; palpi and spinning organ pale, ringed with black;

* Most of the larvae had but five stages; but a few less vigorous ones had six stages. It appears from the widths of head that the larvae grow regularly on the basis of five stages up to the stage IV. It is then a matter of degree of nutrition whether they complete their growth in five stages or in six, in the latter case interpolating an extra stage with an intermediate width of head. This is probably true of all species of the genus and explains the large measurement which I obtained in the case of $C$. erosa (=disstria) in stage III (Psyche, V, 364). The calculated series for $C$. fragilis for the widths of head is $.4 \mathrm{I}, .69$, I.I5, I.92, (2.48), 3.2; ratios .6o and square root of $.60=.774$. 
width $3.2 \mathrm{~mm}$. Body pale blue or blue-gray up to and including the blue band in subdorsal space leaving a few black dots and the row of lateral spots which indent the lower edge of the band. Dorsal space black, the blue dorsal line broken a little in middle of each segment or continuous. Red marks absent or a partly duplicated ad-dorsal line with a few subdorsal dots. Hair all red, thin dorsally, not obscuring the body, quite thick subventrally but not tufted. Venter gray at first, later black, often patched with blue.

Cocoon and pupa as in the other species of Clisiocampa.

Food plants. Willow and poplar (Nash), wild cherry and wild rose (Wiley) and wild gooseberry.

\section{UNCERTAINTY OF THE DURATION OF ANY STAGE IN THE LIFE- HISTORY OF MOTHS.}

\author{
BY CAROLINE G. SOULE, \\ BROOKLINE, MASS.
}

So much emphasis has been laid on the number of moults and the duration of each stage of larval life of our moths, that it seems to me worth while to show a few instances of the variation that occurs. I think that it cannot be stated positively that any species has a certain number of moults, or that any stage lasts a certain number of days.

I have had one brood of $H$. caryae moult four times, and another moult five times. The same difference occurred with $C$. juglandis larvae.

Owing to my arrangements of the larvae there is no-or the minimum-chance of mistake, the moults being always noted from the same boxful of larvae, and those always the first hatched.

The following tables show a few instances of variation among Sphingid larvae.

\section{Cressonia juglandis.}

Stage. $\quad$ 1889. Days. 189r. Days. No. of Dys. Eggs laid July $9 \quad$ July $6 \quad$ r 89 r less

Hatched than r 889 by
“ 2 I 4 " 4 16 3 I 3rd moult Aug. 27 . 5

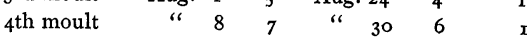
Stopped eating “ 29 2I no record Pupated Sept. 79 " “

\section{Everyx myron.}

Stage. 1889. Days. 1893. Days. No. of Dys.

\begin{tabular}{|c|c|c|c|c|c|c|c|}
\hline Eggs laid & June & 14 & & July & 13 & & $\begin{array}{l}x 893 \text { less } \\
\text { than } x 889 \text { by }\end{array}$ \\
\hline Hatched & June & & 9 & July & 19 & 6 & 3 \\
\hline Ist moult & & 29 & 6 & & 23 & 4 & 2 \\
\hline nd moult & July & 4 & 5 & “ & 27 & 4 & I \\
\hline $3^{\text {rd moult }}$ & " & 8 & 4 & “ & 30 & 3 & I \\
\hline $4^{\text {th moult }}$ & " & 14 & 6 & Aug. & 3 & 4 & 2 \\
\hline Stopped eating & " & 20 & 6 & " & 8 & 5 & I \\
\hline Pupated & " & 27 & 7 & “ & 12 & 4 & 2 \\
\hline
\end{tabular}

\section{Smerinthus astylus.}

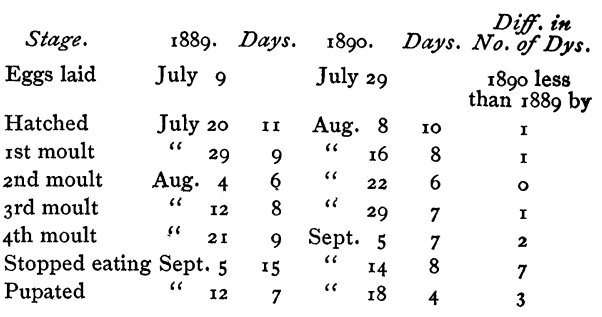

\section{Hemaris diffinis.}

Stage.

Eggs laid

Hatched rst moult and moult 3rd moult $4_{\text {th moult }}$ Stopped eating Pupated 189r. Days. r89r. Days. No. of Dys.

\begin{tabular}{|c|c|c|c|c|c|c|}
\hline no re & ecoro & & July & 7 & & $\begin{array}{l}\text { I89I Ist } \\
\text { brood had }\end{array}$ \\
\hline no re & ecord & & July & I4 & 7 & \\
\hline no re & ecord & & & I7 & 3 & \\
\hline May & & & "6 & 20 & 3 & \\
\hline June & 2 & 3 & " & 23 & 3 & same \\
\hline "6 & 13 & II & " & 27 & 4 & 7 more \\
\hline " & I6 & 5 & Aug & 2 & 6 & I less \\
\hline ، & 18 & 3 & & 7 & 5 & $\begin{array}{l}2 \text { less than } \\
\text { 2nd brood. }\end{array}$ \\
\hline
\end{tabular}



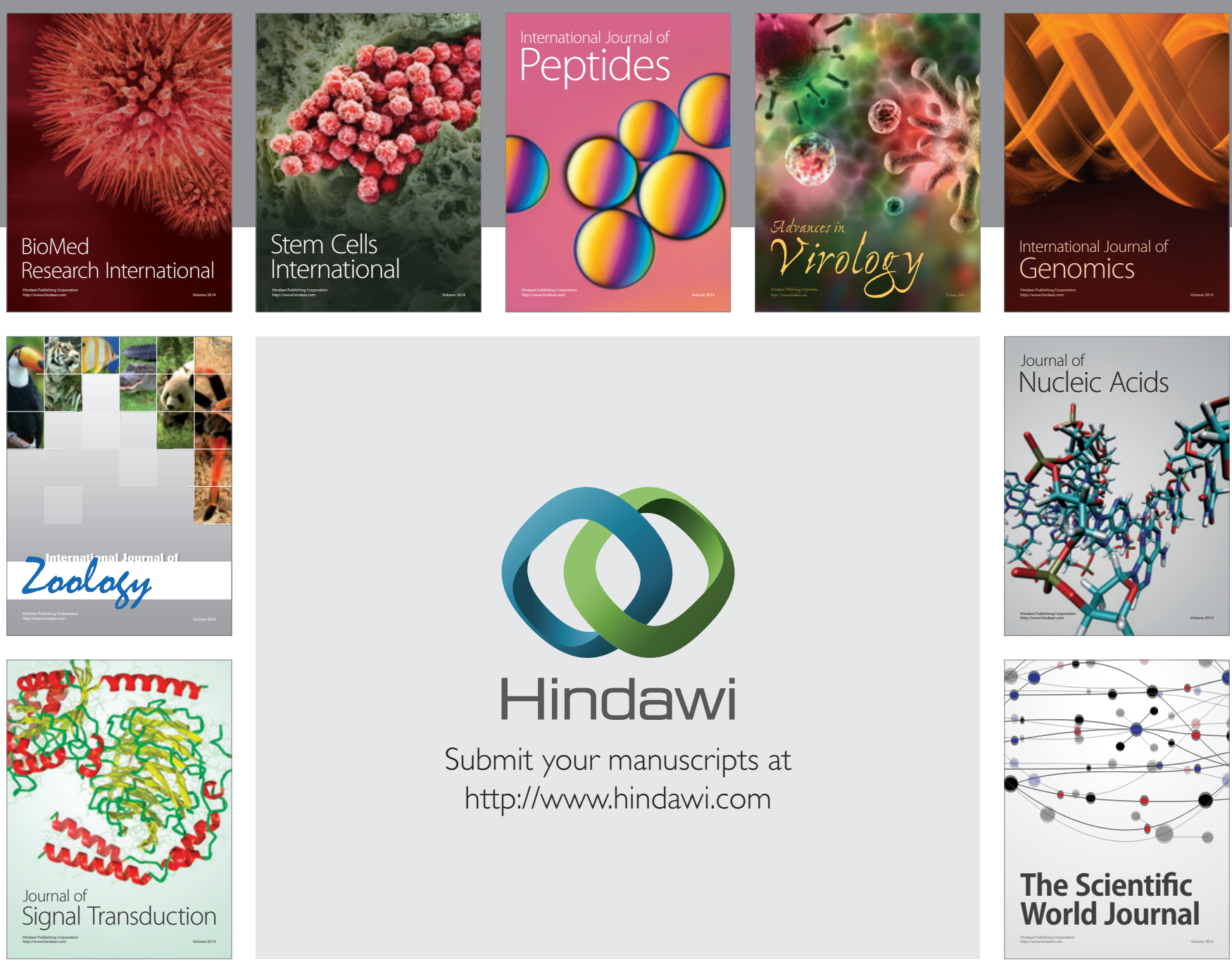

Submit your manuscripts at

http://www.hindawi.com
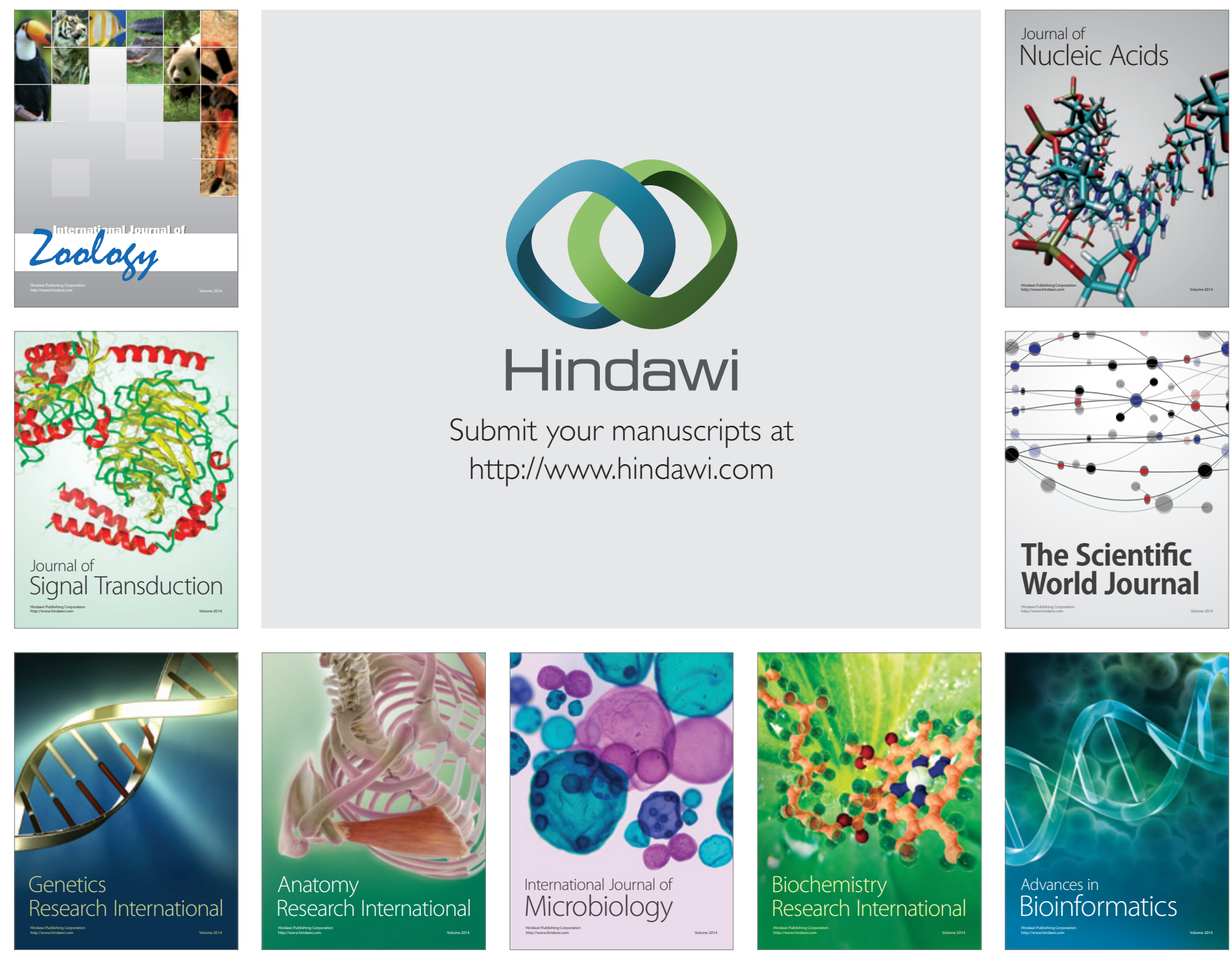

The Scientific World Journal
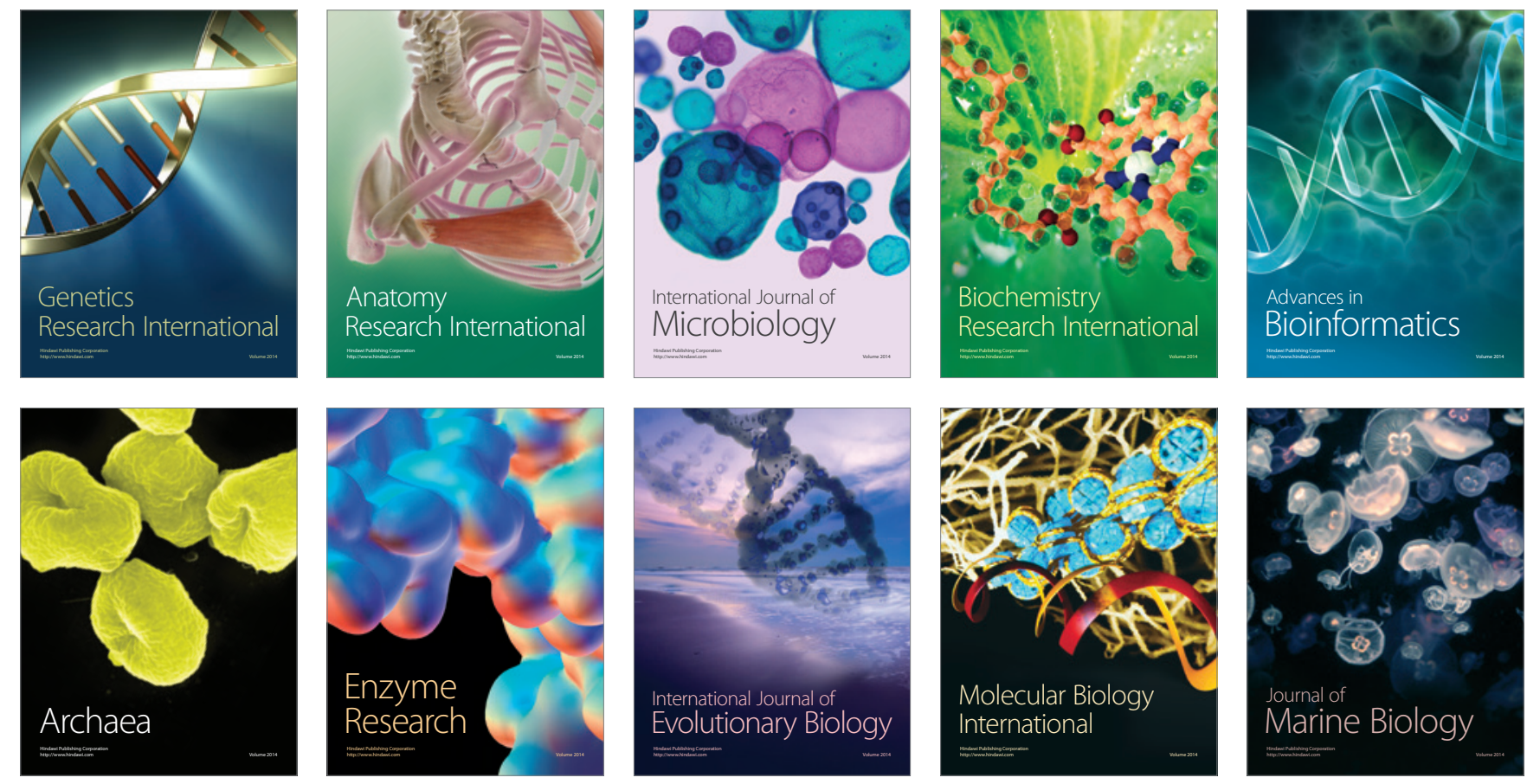